\title{
Proline Uptake in Candida albicans
}

\author{
By NINA DABROWA AND DEXTER H. HOWARD* \\ Department of Microbiology and Immunology, UCLA School of Medicine, \\ Los Angeles, California 90024, U.S.A.
}

(Received 4 March 1981; revised 28 April 1981)

\begin{abstract}
L-Proline entered both mycelial and yeast cells of Candida albicans by an active transport system of high specificity at low $(<0.1 \mathrm{~mm})$ external concentrations of substrate. The apparent $K_{\mathrm{m}}$ value of this system was $0.1 \mathrm{~mm}$ for both types of cells, while the $V$ value was $4 \mathrm{nmol} \mathrm{min}{ }^{-1}$ (mg dry wt) ${ }^{-1}$ for mycelial cells and $1.4 \mathrm{nmol} \mathrm{min}^{-1}$ (mg dry wt) $)^{-1}$ for yeast cells. At L-proline concentrations greater than $0.1 \mathrm{mM}$, the amino acid appeared to enter both morphological forms by diffusion as well as active transport. As saturation was approached diffusion became increasingly important. The higher uptake rate of mycelial cells seemed not to be the result of an inducible system. The optimal pH and temperature for transport of L-proline were 7.0 and $37^{\circ} \mathrm{C}$, respectively. Sodium azide and the proline analogues sarcosine and L-azetidine-2-carboxylic acid inhibited L-proline uptake, while L-thiazolidine-4-carboxylic acid was less effective. The active transport system was highly specific for L-proline since neither ammonium ions, which inhibit the general amino acid transport system of fungi, nor 16 different amino acids interfered substantially with uptake.
\end{abstract}

\section{INTRODUCTION}

Blastospores of the pathogenic fungus Candida albicans (Robin) Berkhout may initiate a mycelial form of growth by germination (Odds, 1979). The formation of germ tubes is fostered by a variety of environmental factors but an incubation temperature of $37^{\circ} \mathrm{C}$ seems mandatory (Odds, 1979).

Among amino acids that induce germination, those that enter the metabolism by conversion to $\alpha$-ketoglutarate are generally the more active (Land et al., 1975), and in our experience proline is one of the most efficient (Dabrowa et al., 1976). A long-term goal of our work is to study the role of proline in germ tube formation by C. albicans. In this paper we describe the characteristics of L-proline transport by blastospores (yeast cells) and germlings (mycelial cells) of C. albicans.

\section{METHODS}

Organism. The strain of Candida albicans used was no. 304 from the Fungus Collection, University of California, Los Angeles, U.S.A. Stock cultures were maintained on glucose peptone agar in a refrigerator and were subcultured every month.

Media and buffers. Glucose peptone agar (GPA), glucose biotin salts medium (GBS) and glucose yeast extract broth (GYE) have been described previously (Dabrowa et al., 1976). The STM-Tris buffer contained $10 \mathrm{mM}-\mathrm{KCl}$, $2.4 \mathrm{~mm}-\mathrm{CaCl}_{2}, 2.5 \mathrm{mM}-\mathrm{MgCl}_{2}$ and $50 \mathrm{~mm}$-Tris, and was titrated to the desired $\mathrm{pH}$ with $6 \mathrm{M}-\mathrm{HCl}$. L-Proline (10 mM) was added to STM-Tris buffer to provide the medium in which the germlings were prepared.

Growth and preparation of the fungal cells. Cells from GPA slants harvested after $24 \mathrm{~b}$ at room temperature were used to inoculate flasks of GBS. These were incubated on a gyrotory shaker (New Brunswick Scientific Co.) for $24 \mathrm{~h}$ at room temperature. Cells were harvested by centrifugation, washed twice and resuspended in STM-Tris buffer (pH 7.2). Such cells were standardized and used as yeast cells in uptake experiments. Germlings, which represented the mycelial cells, were prepared by incubating yeast cells at $37^{\circ} \mathrm{C}$ for $3 \mathrm{~h}$ in STM-Tris buffer 
containing $10 \mathrm{~mm}$-L-proline on a gyrotory shaker. The germlings were centrifuged, washed twice and resuspended in STM-Tris buffer. Standardized suspensions were prepared and used in the uptake experiments.

Measurement of L-proline uptake. Uniformly ${ }^{14} \mathrm{C}$-labelled proline $1294 \mathrm{mCi} \mathrm{mmol}{ }^{-1}\left(10.88 \mathrm{GBq} \mathrm{mmol}^{-1}\right)$; New England Nuclear] was used. The radioactive amino acid was diluted with unlabelled L-proline (Calbiochem) to achieve the desired molar concentrations of the amino acid. The uptake was measured by the method of Gupta \& Howard (1971). Equal volumes of $2 \mu \mathrm{M}$-proline and of cell suspension ( $2 \mathrm{mg}$ dry wt cells $\mathrm{ml}^{-1}$ ) in STM-Tris buffer were placed in separate $50 \mathrm{ml}$ flasks in a water bath shaker (New Brunswick Scientific Co.) and maintained at $37^{\circ} \mathrm{C}$ for $15 \mathrm{~min}$. After temperature equilibration the proline was added to the cell suspension and the flasks were shaken throughout the experiment. At intervals, samples $(1.0 \mathrm{ml})$ were taken and filtered through membrane filters $(0.45 \mu \mathrm{m})$, and portions $(0.5 \mathrm{ml})$ of the filtrate were used to measure the radioactivity remaining. The decrease in radioactivity at various times compared with the whole suspension represented the uptake of $L$-proline. The scintillation fluid contained the following chemicals per litre of dioxan: naphthalene, $70 \mathrm{~g} ; 2,5$-diphenyloxazole, $7 \mathrm{~g}$; 1,4-bis-2-(5-phenyloxazolyl)benzene, $0.05 \mathrm{~g}$. The vials were counted for $10 \mathrm{~min}$ in a Beckman scintillation counter, model LS 3133T, and the counts were corrected for background. Other details of the procedures involved in uptake measurements have been published previously (Dabrowa \& Howard, 1976; Gupta \& Howard, 1971; Tang \& Howard, 1973).

\section{RESULTS}

\section{Initiation of blastospore germination}

L-Proline triggers the germination of Bacillus megaterium spores but neither uptake nor metabolism of the amino acid is required for it to function as an inducer (Rossignol \& Vary, 1979). Preliminary experiments were conducted to see whether or not such a triggering mechanism was operative in the L-proline-induced germination of $C$. albicans blastospores. Washed yeast cells from cultures in GBS medium incubated at $23^{\circ} \mathrm{C}$ for $24 \mathrm{~h}$ were exposed to $10 \mathrm{mM}$-L-proline in STM-Tris buffer (pH 7.2) at $37^{\circ} \mathrm{C}$. Samples were withdrawn at intervals, washed once and resuspended in buffer at $37^{\circ} \mathrm{C}$. The percentage of germination among buffer-resuspended cells is shown in Table 1. Cells harvested from GBS did not germinate in buffer which did not contain the inducer. Virtually no germination was seen in cells harvested after $15 \mathrm{~min}$ exposure to proline. After $30 \mathrm{~min}$ a substantial number of the exposed cells germinated, and by 45 to $60 \mathrm{~min}$ most of the cells completed germination in the absence of the inducer. In fact, a large number (80\%) of the cells harvested at $60 \mathrm{~min}$ had very small germ tubes that continued to elongate in the buffer medium. Thus, proline did not act as a simple trigger device in the germination of $C$. albicans blastospores. A substantial period of exposure to, and presumably metabolism of, the amino acid was required for germination to take place.

Table 1. Initiation of germination of Candida albicans blastospores after exposure to L-proline for various times

Cells grown at $23^{\circ} \mathrm{C}$ in GBS were harvested, washed, and resuspended in $10 \mathrm{mM}$-L-proline in buffer and incubated at $37^{\circ} \mathrm{C}$. Cells were harvested at the indicated times, washed and resuspended in buffer at $37^{\circ} \mathrm{C}$. The percentage of the blastospores which germinated was recorded after $3 \mathrm{~h}$.

Time of exposure

$\begin{array}{cc}\text { to L-proline } & \text { Germination } \\ (\mathrm{min}) & (\%)\end{array}$

$\begin{array}{rr}0 & 0 \\ 15 & 2 \\ 30 & 33 \\ 45 & 71 \\ 60 & 80 \\ 75 & 80 \\ 180 & 95\end{array}$


Table 2. Germination of the blastospores of Candida albicans at different stages of growth tested in two media

\begin{abstract}
Cells harvested from GYE broth were washed in saline and inoculated into flasks of fresh GYE broth. Cultures were incubated at $23{ }^{\circ} \mathrm{C}$ on a gyrotory shaker. The numbers of cells ml-1 were determined by direct microscopic count in a haemocytometer. At the indicated times, a sample was removed and the cells were recovered by centrifugation. The cells were washed once and resuspended $\left(5 \times 10^{6}\right.$ cells $\mathrm{ml}^{-1}$ ) in $10 \mathrm{~mm}$-proline buffer or lamb's serum (Gibco, U.S.A.) at $37^{\circ} \mathrm{C}$. The percentage of the blastospores which germinated was recorded after $3 \mathrm{~h}$.
\end{abstract}

$\begin{array}{rccc}\begin{array}{c}\text { Time } \\ \text { (h) }\end{array} & \begin{array}{c}10^{-7} \times \\ \text { No. of cells } \\ \mathrm{ml}^{-1}\end{array} & \begin{array}{c}\text { In } \\ \text { proline buffer }\end{array} & \begin{array}{c}\text { In } \\ \text { serum }\end{array} \\ 0 & 0.7 & 66 & 90 \\ 1 & 0.7 & 90 & 95 \\ 2 & 1.0 & 88 & 95 \\ 3 & 1.0 & 90 & 98 \\ 4 & 1.4 & 76 & 95 \\ 5 & 1.7 & 44 & 96 \\ 6 & 2.2 & 18 & 95 \\ 7 & 2.4 & 2 & 90 \\ 8 & 4.5 & 2 & 95 \\ 9 & 6.5 & 0 & 95 \\ 10 & 8.0 & 0 & 96 \\ 24 & 20.0 & 60 & 95\end{array}$

\title{
Germination of blastospores at different stages of growth
}

Soll \& Bedell (1978) have confirmed an earlier observation of Chaffin \& Sogin (1976) that a temperature shift (from 25 to $37^{\circ} \mathrm{C}$ ) induced germination of the blastospores of C. albicans in amino acid-containing defined media only after the cells had entered a stationary phase of growth. When cells began to proliferate at $25^{\circ} \mathrm{C}$, a temperature shift no longer induced germination (Soll \& Bedell, 1978). Since such a commitment might influence our studies on amino acid uptake we re-examined this point. Table 2 shows that blastospores in stationary phase ( 0 time and $24 \mathrm{~h}$ ) germinated when placed in proline buffer and that the percentage of germination decreased as the cells entered an exponential phase of growth (4-10 h). Interestingly, this commitment was only apparent in the synthetic medium. In serum, even rapidly dividing cells germinated promptly after shift to $37^{\circ} \mathrm{C}$. Accordingly, we germinated stationary phase cells in proline buffer to obtain the germlings used for comparative studies (see Methods).

\section{Time course of uptake of $\mathrm{L}$-proline}

The time course of L-proline uptake by yeast and mycelial cells of C. albicans is shown in Fig. 1. Both types of cells accumulated the amino acid as a linear function of time until the exogenous supply became limiting. There was no lag in uptake and the amino acid in the soluble pool first increased and then rapidly decreased. The initial velocity was higher in mycelial cells than in yeast cells.

An inducible transport system for L-proline in C. albicans has been described (Jayakumar et al., 1979). Since the mycelial phase cells were germlings induced by incubation in proline, the higher rate of uptake might have been due to this preliminary exposure to the amino acid. To investigate this possibility, cells germinated in glutamic acid were tested for proline uptake. Figure 2 shows there was no enhancement of the uptake of L-proline in proline-germinated cells as compared to glutamic acid-germinated cells. These results, together with the specificity of the proline transport system (see below), suggested that the increased uptake by the mycelial cells was not due to an induced transport system. 


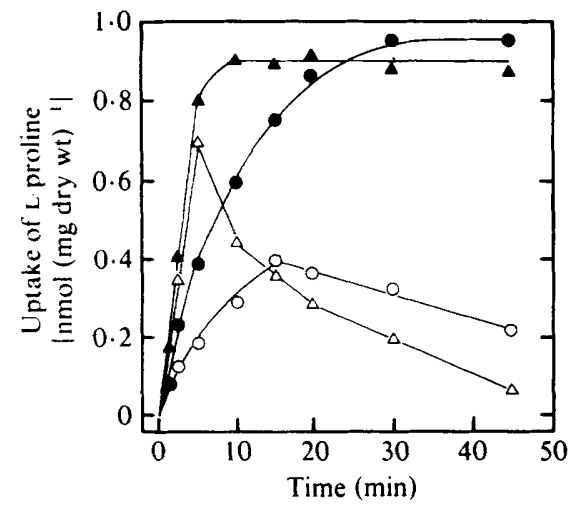

Fig. 1

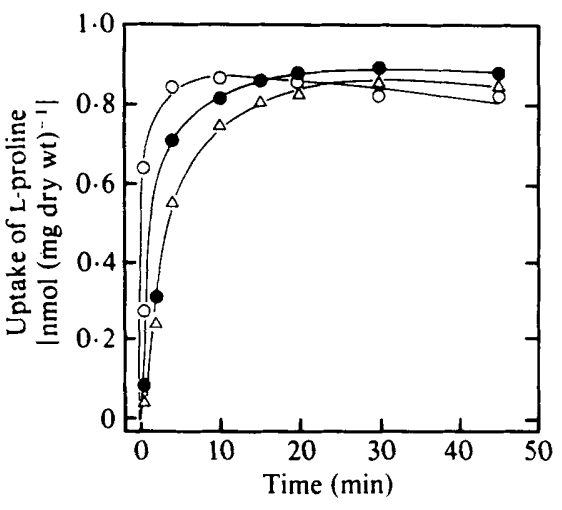

Fig. 2

Fig. 1. Time course of uptake of L-proline by yeast and mycelial cells of Candida albicans at $37{ }^{\circ} \mathrm{C}$. The system contained $1 \mathrm{nmol}$ L-proline and $1.0 \mathrm{mg}$ dry wt cells per $\mathrm{ml} \mathrm{STM-Tris} \mathrm{buffer}(\mathrm{pH} \mathrm{7.0)}$. $\Delta$. Total uptake by mycelial cells; $\triangle$, cold trichloroacetic acid (TCA)-soluble fraction in mycelial cells; - total uptake by yeast cells; $O$, cold TCA-soluble fraction in yeast cells.

Fig. 2. Time course of uptake of L-proline by mycelial cells of Candida albicans germinated in proline or in glutamic acid. The system contained $1 \mathrm{nmol}$ L-proline and $1.0 \mathrm{mg}$ dry wt cells per $\mathrm{ml} \mathrm{STM-Tris}$ buffer ( $\mathrm{pH} 7.0$ ). Cells germinated in $10 \mathrm{mM}$-L-glutamic acid; $\triangle$, cells germinated in $10 \mathrm{mM}$-L-proline; $O$, cells germinated in $10 \mathrm{mM}$-L-glutamic acid, and then kept for $40 \mathrm{~min}$ in $10 \mathrm{mM}$-L-proline and washed before use.

\section{Kinetics of L-proline uptake}

Neither of the two morphological forms showed complete saturation kinetics. At low external concentrations of $\mathrm{L}$-proline $(10 \mu \mathrm{M}$ to $0.1 \mathrm{mM})$ the rate of uptake of the amino acid by yeast and mycelial cells increased rapidly with increasing external concentration. This rapid increase started to diminish when the external concentration of L-proline was about $0.1 \mathrm{~mm}$; any further increase in the external concentration resulted in a slow but linear increase in the initial rate of L-proline uptake. Although the transport system did not exhibit simple Michaelis-Menten kinetics, an apparent $K_{\mathrm{m}}$ value of $0.1 \mathrm{~mm}$ for both yeast and mycelial cells was obtained by calculation. The results indicated that $L$-proline was transported by two systems. At low external concentrations a permease system was operative; however, at higher external concentrations (greater than $0.1 \mathrm{~mm}$ ) the amino acid was also entering the cells by diffusion. As saturation was approached, diffusion became increasingly important in uptake of the amino acid. The calculated $V$ value for the permease-like system of mycelial cells was approximately threefold higher $\left[4 \mathrm{nmol} \mathrm{min}{ }^{-1}(\mathrm{mg}\right.$ dry wt $\left.)^{-1}\right]$ than that of the yeast cells $\left[1.4 \mathrm{nmol} \min ^{-1}(\mathrm{mg} \text { dry } w \mathrm{t})^{-1}\right]$.

\section{Effect of temperature and $p H$ on L-proline uptake}

Further evidence that a permease-like system was operative at low external concentrations of substrate was derived from the studies on the effect of temperature and $\mathrm{pH}$ on uptake. Only yeast cells were studied in this way. The optimum $\mathrm{pH}$ was 7.0 and the rate of uptake was fastest at $37^{\circ} \mathrm{C}$.

\section{Inhibition of L-proline uptake by metabolic inhibitors, analogues and ammonium ions}

Sodium azide markedly inhibited proline uptake by both morphological forms of $C$. albicans, but 2,4-dinitrophenol and arsenate were far less efficient in inhibition of uptake (Table 3). Sarcosine and L-azetidine-2-carboxylic acid were effective analogue inhibitors of L-proline uptake, while L-thiazolidine-4-carboxylic acid had much less of an effect at the 
Table 3. Inhibition of L-proline uptake of Candida albicans by metabolic inhibitors, analogues and ammonium ions

\begin{tabular}{lcc}
\multicolumn{1}{c}{$\begin{array}{l}\text { Inhibitor } \\
(1 \mathrm{mM})\end{array}$} & $\overbrace{\text { Yeast cells }}^{\text {Rate of uptake of L-proline }(\% \text { of control })^{*}}$ \\
Sodium azide & 12 & Mycelial cells \\
Sodium arsenate & 71 & 25 \\
2,4-Dinitrophenol & 82 & 86 \\
Sarcosine & 24 & 89 \\
L-Azetidine-2-carboxylic acid & 53 & 61 \\
L-Thiazolidine-4-carboxylic acid & 71 & 86 \\
Ammonium chloride & 106 & 97
\end{tabular}

* In controls (i.e. in the absence of inhibitor), the initial rates of uptake of L-proline $(1 \mu \mathrm{M})$ were $0.17 \mathrm{nmol}$ $\mathrm{min}^{-1}(\mathrm{mg} \mathrm{dry} \mathrm{wt})^{-1}$ for yeast cells and $0.36 \mathrm{nmol} \mathrm{min}^{-1}(\mathrm{mg} \text { dry wt})^{-1}$ for mycelial cells.

Table 4. Effect of different amino acids on L-proline uptake by Candida albicans

\begin{tabular}{|c|c|c|}
\hline \multirow{2}{*}{$\begin{array}{l}\text { Unlabelled } \\
\text { competitor } \\
\text { (1 mM) }\end{array}$} & \multicolumn{2}{|c|}{ Rate of uptake of L-proline ( $\%$ of control) ${ }^{*}$} \\
\hline & Yeast cells & Mycelial cells \\
\hline L-Alanine & 70 & 68 \\
\hline L-Arginine & 80 & ND \\
\hline L-Cysteine & 72 & 90 \\
\hline L-Cystine & 86 & 85 \\
\hline L-Glutamic acid & 73 & 90 \\
\hline Glycine & 96 & 80 \\
\hline L-Histidine & 89 & 95 \\
\hline L-Isoleucine & 94 & 90 \\
\hline L-Leucine & 71 & 80 \\
\hline L-Lysine & 108 & 110 \\
\hline L-Methionine & 80 & 95 \\
\hline L-Phenylalanine & 82 & 90 \\
\hline L-Serine & 126 & 100 \\
\hline L-Tryptophan & 100 & 108 \\
\hline L-Tyrosine & 130 & 110 \\
\hline L-Valine & 108 & 120 \\
\hline
\end{tabular}

ND, Not determined.

- In controls (i.e. in the absence of competitor amino acid), the initial rates of uptake of $\mathrm{L}$-proline $(1 \mu \mathrm{M})$ were

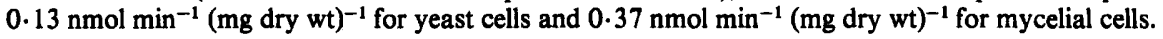

concentration tested ( $1 \mathrm{mM})$. Ammonium ions, which are known to inhibit general transport systems, did not affect the uptake of L-proline by C. albicans.

\section{Effect of other amino acids on L-proline transport}

The addition of any one of 16 different amino acids had very little effect on the uptake of L-proline by yeast or mycelial cells (Table 4). Modification of uptake varied from $30 \%$ inhibition to $30 \%$ enhancement among the different amino acids. The failure of other amino acids to inhibit substantially L-proline uptake emphasizes the specificity of the active transport system.

\section{DISCUSSION}

Proline triggers the germination of Bacillus megaterium spores (Rossignol \& Vary, 1979). However, neither uptake nor metabolism of the amino acid was necessary to initiate 
germination because (i) only a brief exposure (30 s) to the trigger was required, (ii) the enzymes required for proline metabolism were not present in the spores, (iii) several non-metabolizable analogues of L-proline were effective triggers, (iv) germination occurred in the presence of inhibitors of oxygen uptake and metabolism, and (v) uptake of proline occurred after germination had been triggered. Proline does not function as such a trigger in the germination of the blastospores of Candida albicans where several minutes of exposure to proline, and thus some metabolism of it, is required for the amino acid to sponsor germination (Table 1).

Chaffin \& Sogin (1976) presented evidence, derived from a study of yeast cell size, which indicated that germination of blastospores could be induced only in stationary phase cells incubated at $37^{\circ} \mathrm{C}$ in a defined medium consisting of amino acids (Lee et al., 1975). Budding cells in an exponential phase of growth did not germinate when incubated at $37^{\circ} \mathrm{C}$ in the same medium. Soll \& Bedell (1978) have expanded the observations of Chaffin \& Sogin and have established that a 'commitment point' is passed by cells growing at $25^{\circ} \mathrm{C}$ after which they cannot be induced to form germ tubes by incubation at $37^{\circ} \mathrm{C}$ until they again enter the stationary phase. However, actively budding cells can be induced to germinate by certain substances such as serum (Mattia \& Cassone, 1979). Our results confirm the findings of both Soll \& Bedell (1978) and Mattia \& Cassone (1979), but it should be noted that a complex medium such as serum may have effects other than induction of germination. For example, serum may inhibit bud formation and thus evoke stationary phase conditions in the yeast cells which then respond to the effects of amino acids or other inducers in the medium. The factors involved in germination are diverse and much still needs to be done to sort out seemingly conflicting observations.

Inducible proline transport systems have been described in both bacteria and yeasts (Jayakumar et al., 1978, 1979; Kay \& Gronlund, 1969; Schwencke \& Magaña-Schwencke, 1979). The kinetics of proline uptake in C. albicans studied by Jayakumar et al. (1979) showed that the $K_{\mathrm{m}}$ for preincubated or proline-grown cells was similar to that of normal cells. In contrast, the $V$ values of proline-grown or preincubated cells were 7-13 times higher than those of the normal cells. The germlings used for mycelial cells in our work were prepared in proline buffer. Thus, one could argue that the threefold greater $V$ value obtained with mycelial cells might have been due to induction of a different proline permease. However, this appeared not to be the case, because both glutamic acid-germinated cells, and glutamic acid-germinated cells subsequently incubated in proline, exhibited virtually the same velocity of initial uptake as did proline-germinated cells.

Many multiple transport systems have been described in bacteria (Guardiola et al., 1974; Menzel \& Roth, 1980) and in fungi (Breton \& Surdin-Kerjan, 1977; Tang \& Howard, 1973). For example, among fungi, Cryptococcus albidus takes up L-glutamic acid by two saturable systems: a high-affinity system $\left(K_{\mathrm{m}} 11.5 \mu \mathrm{M}\right)$ and a low-affinity system $\left(K_{\mathrm{m}} 2.5 \mathrm{mM}\right)$ (Tang \& Howard, 1973). L-Leucine and L-proline enter the cells of Histoplasma capsulatum by high-affinity systems $\left(K_{\mathrm{m}} 20 \mu \mathrm{M}\right.$ and $\left.17 \mu \mathrm{M}\right)$ and by simple diffusion (Dabrowa \& Howard, 1976; Gupta \& Howard, 1971). Low-affinity systems may be difficult to distinguish from diffusion (Tang \& Howard, 1973). Blastomyces dermatitidis transports L-leucine by a high-affinity system $\left(K_{\mathrm{m}} 11 \mu \mathrm{M}\right)$ and by diffusion (Bowdon \& Garrison, 1974). In the present study, L-proline was noted to enter the cells by two systems. At low substrate concentrations (10 $\mu \mathrm{M}$ to $0.1 \mathrm{mM}$ ) an active transport system which was (i) highly specific for proline, (ii) uninhibited by ammonium ions, (iii) temperature and $\mathrm{pH}$ dependent, and (iv) inhibited by sodium azide was demonstrable. At high substrate concentrations $(0.2$ to $0.5 \mathrm{mM})$ the active transport system was accompanied by diffusion. As saturation was approached diffusion became increasingly important.

Among the analogues studied, sarcosine strongly inhibited proline uptake. This suggests that the accumulation of L-proline and sarcosine are mediated by the same uptake system. Moreover, the somewhat smaller but demonstrable effects of L-azetidine-2-carboxylic acid 
and L-thiazolidine-4-carboxylic acid suggest there is a general imino acid transport system in C. albicans similar to that observed in Saccharomyces chevalieri (Kuznar et al., 1973; Magaña-Schwencke \& Schwencke, 1969; Magaña-Schwencke et al., 1973). The fact that glycine and alanine were transported by the system in $S$. chevalieri but not by the one reported in this paper indicates some differences between the two systems. The inhibition of germination of $C$. albicans in proline-buffer medium exerted by some of these analogues (Dabrowa et al., 1976) could be related to antagonism of uptake of L-proline.

This investigation was supported by Public Health Service grant AI-16252 from the National Institute of Allergy and Infectious Diseases, N.I.H., Bethesda. We thank Dr Rishab K. Gupta for advice during the course of the work and for thoughtful criticism of the manuscript. We are grateful to Ms Lois Howard and to Ms Judy Fung for their care in preparing the manuscript. This is publication no. 4 of the Collaborative California Universities-Mycology Research Unit (CCU-MRU).

\section{REFERENCES}

Bowdon, R. E. \& GaRRison, R. C. (1974). The uptake and incorporation of leucine and cystine by the mycelial and yeast-like phases of Blastomyces dermatitidis. Mycopathologia et mycologia applicata $54,421-433$.

Breton, A. \& Surdin-Kerjan, Y. (1977). Sulfate uptake in Saccharomyces cerevisiae. Journal of Bacteriology 132, 224-232.

Chaffin, W. L. \& Sogin, S. J. (1976). Germ tube formation from zonal rotor fractions of Candida albicans. Journal of Bacteriology 126, 771-776.

Dabrowa, N. \& Howard, D. H. (1976). Uptake of L-proline by Histoplasma capsulatum. Canadian Journal of Microbiology 22, 1188-1190.

Dabrowa, N., TAXer, S. S. S. \& Howard, D. H. (1976). Germination of Candida albicans induced by proline. Infection and Immunity 13, 830-835.

Guardiola, J., De Felice, M., Klopotowski, T. \& IACCARINO, M. (1974). Multiplicity of isoleucine, leucine, and valine transport systems in Escherichia coli K-12. Journal of Bacteriology 117, 382-392.

GuPTA, R. K. \& Howard, D. H. (1971). Comparative physiological studies of the yeast and mycelial forms of Histoplasma capsulatum: uptake and incorporation of L-leucine. Journal of Bacteriology 105, 690-700.

Jayakumar, A., Singh, M. \& Prasad, R. (1978). Characteristics of proline transport in normal and starved cells of Candida albicans. Biochimica et biophysica acta 513, 348-355.

Jayakumar, A., Singh, M. \& Prasad, R. (1979). An inducible proline transport system in Candida albicans. Biochimica et biophysica acta 556, 144150.

Kay, W. W. \& Gronlund, A. F. (1969). Proline transport by Pseudomonas aeruginosa. Biochimica et biophysica acta 193, 444-455.

KuZNAR, J., SCHWENCKE, J. \& MAGAÑa-SchWENCKe, N. (1973). Sarcosine and imino acid uptake in Saccharomyces chevalieri. Biochimica et biophysica acta 318, 273-280.

Land, G. A., McDonald, W. C., StJernholm, R. L.
\& Friedman, L. (1975). Factors affecting filamentation in Candida albicans: relationship of the uptake and distribution of proline to morphogenesis. Infection and Immunity 11, 1014-1023.

LeE, K. L., Buckley, H. R. \& Campbell, C. C. (1975). An amino acid liquid synthetic medium for development of mycelial and yeast forms of Candida albicans. Sabouraudia 13, 148-153.

MAGaña-SchWencke, N. \& SChWENCKe, J. (1969). A proline transport system in Saccharomyces chevalieri. Biochimica et biophysica acta 173, 313-323.

MAGAÑA-SchWENCKe, N., Kuznar, J. \& SCHWENCKE, J. (1973). Imino acid transport in yeast: the uptake of sarcosine. Biochimica et biophysica acta 318, 281-288.

Mattia, E. \& Cassone, A. (1979). Inducibility of germ-tube formation in Candida albicans at different phases of yeast growth. Journal of General Microbiology 113, 439-442.

MENZEL, R. \& RoTH, J. (1980). Identification and mapping of a second proline permease in Salmonella typhimurium. Journal of Bacteriology 141, 10641070.

Odds, F. C. (1979). Candida and Candidosis. Baltimore: University Park Press.

Rossignol, D. P. \& VARY, J. C. (1979). Biochemistry of L-proline triggered germination of Bacillus megaterium spores. Journal of Bacteriology 138, $431-441$.

Schwencke, J. \& Magaña-Schwencke, N. (1969). Derepression of a proline transport system in Saccharomyces chevalieri by nitrogen starvation. Biochimica et biophysica acta 173, 302-312.

Soll, D. R. \& Bedell, G. W. (1978). Bud formation and the inducibility of pseudo-mycelium outgrowth during release from stationary phase in Candida albicans. Journal of General Microbiology 108, 173-180.

TANG, S. L. \& HowARD, D. H. (1973). Uptake and utilization of glutamic acid by Cryptococcus albidus. Journal of Bacteriology 115, 98-106. 